\title{
Clinical, virological and immunological features of primary HIV-1 infection
}

\author{
M D de Jong, H J Hulsebosch, J M A Lange
}

\section{Introduction}

Primary infection with human immunodeficiency virus (HIV) has been defined by the Centers for Disease Control (CDC) as a mononucleosis-like illness, with or without aseptic meningitis, associated with seroconversion for HIV antibody. ${ }^{1}$

Since the introduction of this definition in 1986, it has become clear that symptomatic primary human immunodeficiency virus type 1 (HIV-1) infection can be a recognisable clinical syndrome with distinct differences from Epstein-Barr virus (EBV) infectious mononucleosis. Moreover, the CDC definition does not encompass the full clinical spectrum of primary HIV-1 infection.

We will outline the syndrome of primary infection with HIV-1 by reviewing clinical, virological and immunological features. Differential diagnostic considerations will also be discussed.

\section{Clinical findings}

Primary infection with HIV-1 is symptomatic in the majority of cases. An acute clinical illness during the period of seroconversion has been reported with an incidence ranging from 53 to $93 \%$ of patients. ${ }^{2-6}$ The time from infection with HIV-1 to the onset of clinical illness seems to vary between 1 and 4 weeks for the mononucleosis-like illness, and up to 6 weeks for neurological symptoms. ${ }^{37-14}$ The duration of the illness ranges from a few days to 2 months, depending on the severity of symptoms. ${ }^{35915}$ A duration of more than 14 days seems to predispose to an early progression of HIV-1 infection to AIDS. ${ }^{4}$

Symptomatic primary infection with HIV-1 is most commonly described as an influenza- or mononucleosis-like illness of varying severity. Although a

Department of Internal Medicine, AIDS-unit MD de Jong, JMA Lange

National AIDS Therapy Evaluation Centre MD de Jong, JMA Lange

Department of Dermatology and Venereology Academic Medical Centre, University of Amsterdam, The Netherlands

HJ Hulsebosch large variety of symptoms and signs have been described in association with this illness, the most frequently reported clinical features are fever, malaise, diarrhoea, myalgia, arthralgia, sore throat, headaches, lymphadenopathy and a maculopapular rash. However, there is no unanimity on the frequency of occurrence of the various symptoms (table 1)..$^{-55-39}$

The acute illness is almost always febrile with temperatures ranging from $38^{\circ}$ to $40^{\circ} \mathrm{C}$, sometimes accompanied by chills. Nightsweats have also been reported in a number of patients. ${ }^{317} 192040$

The most common oropharyngeal symptom is a sore throat, which in more severe cases may lead to odynophagia. . $^{3-5} 89$ 15-17 21-3340 $^{1}$ On examination varying degrees of pharyngeal oedema and hyperaemia without tonsillar enlargement or plaques are usually seen. Enanthem with oral ulceration appears to be a distinctive sign of primary infection with HIV-1. Ulcers have been described on the buccal mucosa, gingiva, palate and in the oeso-

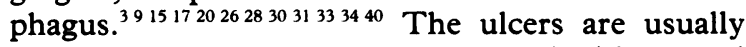
round or oval and sharply demarcated with normal appearing surrounding mucosa. They may be covered by an exudative plaque. A typical example of such an ulcer is presented in fig 1 . Similar ulcers have also been described on the anus and penis. ${ }^{9128}$ In a small number of patients oral, and even oesophageal candidiasis have been reported..$^{4} 1733540$ These manifestations of immune deficiency do not persist after the acute illness and reflect a transient suppression of the immune system. They should thus not be considered AIDS-indicator diagnoses.

Gastrointestinal manifestations of primary HIV-1 infection include diarrhoea, anorexia and nausea, sometimes with vomiting. ${ }^{3-5} 9$ 13-17 $19202426-33$ 36-38 Some patients may complain of abdominal pain. ${ }^{5131923293336}$

As emphasised in the CDC definition, the most common neurological manifestation of primary HIV-1 infection is an aseptic meningoencephalitis. Complaints of headaches, photophobia and retroorbital pain may reflect this involvement of the nervous system. ${ }^{35131417242730-33 \text { 38-40 Incidental }}$ neurological findings attributed to primary HIV-1 infection include encephalopathy, ${ }^{14}$ peripheral neuropathy, ${ }^{27} 37$ myelopathy, ${ }^{40}$ brachial neuritis, ${ }^{34}$ facial palsy, ${ }^{371}$ and Guillain-Barré syndrome. ${ }^{32}{ }^{22}$ In 
Table 1 Frequency of symptoms reported in primary HIV-1 infection (\%)

\begin{tabular}{|c|c|c|c|c|c|c|c|}
\hline $\begin{array}{l}\text { Symptoms and } \\
\text { signs }\end{array}$ & $\begin{array}{l}\text { Cooper }^{3} \\
n=46\end{array}$ & $\begin{array}{l}\text { Tindall }^{5} \\
\mathrm{n}=39\end{array}$ & $\begin{array}{l}\text { Gaines }^{9} \\
\mathrm{n}=20\end{array}$ & $\begin{array}{l}\text { v. Sydow } \\
\mathrm{n}=21\end{array}$ & $\begin{array}{l}\text { Rabeneck } \\
\mathrm{n}=16\end{array}$ & $\begin{array}{l}\text { Pedersen } \\
\mathrm{n}=46\end{array}$ & $\begin{array}{l}\text { Cases }^{\star} \\
n=48\end{array}$ \\
\hline $\begin{array}{l}\text { Fever } \\
\text { Rash } \\
\text { Lymphadenopathy } \\
\text { Sore throat } \\
\text { Nausea } \\
\text { Diarrhoea } \\
\text { Myalgia } \\
\text { Arthralgia } \\
\text { Headache }\end{array}$ & $\begin{array}{l}92 \\
50 \\
75 \\
75 \\
67 \\
33 \\
\}_{58} 95\end{array}$ & $\begin{array}{l}77 \\
23 \\
44 \\
56 \\
31 \\
28 \\
56 \\
49 \\
49\end{array}$ & $\begin{array}{r}100 \\
80 \\
95 \\
95 \\
\text { n.r. } \\
30 \\
40 \\
\text { n.r. } \\
\text { n.r. }\end{array}$ & $\begin{array}{r}100 \\
86 \\
95 \\
95 \\
48 \\
38 \\
43 \\
\text { n.r. } \\
\text { n.r. }\end{array}$ & $\begin{array}{l}\text { n.r. } \\
81 \\
44 \\
63 \\
\text { n.r. } \\
44 \\
69 \\
\text { n.r. } \\
44\end{array}$ & $\begin{array}{r}100 \\
46 \\
78 \\
67 \\
\text { n.r. } \\
20 \\
\}_{\text {n.r. }} 35\end{array}$ & $\begin{array}{l}94 \\
79 \\
65 \\
56 \\
10 \\
33 \\
44 \\
23 \\
33\end{array}$ \\
\hline
\end{tabular}

n.r.: not reported

$\star$ : review of 48 reported cases of primary HIV-1 infection ${ }^{810-1518-39}$

most cases these manifestations are self-limiting, although a neurological deficit after the illness has been reported. ${ }^{34}$ Irritability and depression during the illness have also been reported..$^{514}$

Primary HIV-1 infection is often accompanied by myalgia. . $^{3-1013-1721-242730-3339}$ Increased levels of serum creatinine kinase in association with myalgia and muscle weakness have been reported in three cases..$^{5233}$ In one case, primary HIV-1 infection was associated with rhabdomyelysis, acute renal failure and nephrosis. ${ }^{22}$ Although less consistently reported, arthralgia also appears to be a common complaint. $^{3-581013152830313339}$

Pulmonary symptoms are infrequently reported. Some patients may complain of a dry cough without dyspnoea. ${ }^{4515340}$ Two cases of acute pneumonitis have been reported..$^{24} 33$

The most common findings on physical examination are fever, lymphadenopathy and a rash (table 1). Lymphadenopathy usually occurs in the second week of the illness and in most cases persists after the illness, although lymph nodes may gradually decrease in size. Axillary, occipital and cervical lymph nodes are most frequently involved, but the lymphadenopathy may be generalised. Mild splenomegaly has also been reported in a small number of patients. ${ }^{11172021313740}$

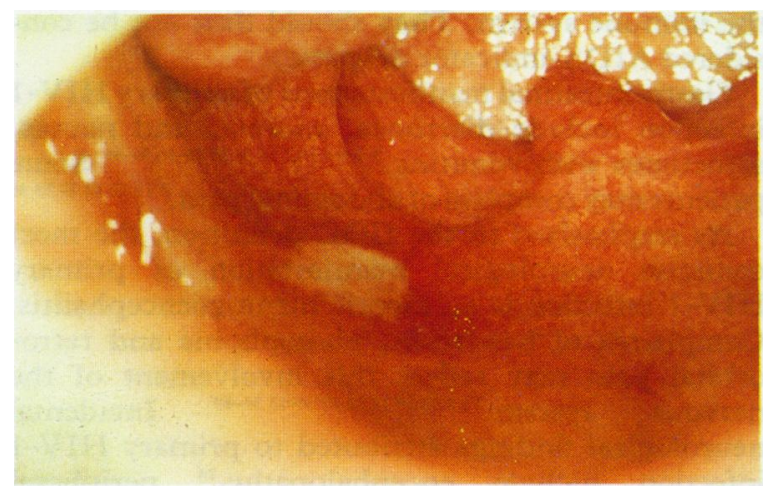

Fig 1 Oral ulceration and enanthem in a patient with primary $H I V$ infection.
In the majority of cases a non-pruritic rash develops early during the acute illness. The rash consists of round or oval erythematous macular or maculopapular lesions with a diameter of 5-30 mm. Slight roseola-like desquamation may be present at the edges (fig 2), while the centre of the lesions can be haemorrhagic or may be covered by a crust. ${ }^{43}$ In most cases the exanthem is symmetrically distributed over the trunk and face, but the extremities may also be affected, including the palms and soles (fig 3). The rash generally resolves within 1-3 weeks. Microscopic examination of biopsy specimens shows a lymphohistiocytic infiltrate around blood vessels and adnexae in a more or less oedematous papillary dermis. The infiltrate may contain plasma cells and there may be some extravasation of erythrocytes. The epidermis sometimes shows some exocytosis and parakeratosis. ${ }^{43}$ However, microscopic findings are not diagnostic for HIV exanthem. Immunohistological examination shows that the infiltrate predominantly consists of $\mathrm{CD} 4+$ lymphocytes. Moreover, HIV p24 antigen can be detected in occasional cells, possibly Langerhans' cells, of the infiltrate. It is possible that these cells present HIV p24 antigen to CD4 + lymphocytes, leading to a delayed type hypersensitivity reaction. ${ }^{20}$ Incidental dermatological findings include a vesiculopustular exanthem and enanthem, ${ }^{34}$ diffuse urticaria ${ }^{13}$ and alopecia. ${ }^{1315}$

Symptomatic primary infection with human immunodeficiency virus type 2 (HIV-2), which is mainly prevalent in Western Africa, has been reported in only one case ${ }^{44}$ Lasting a few days, the illness consisted of fatigue, shivering, tender cervical lymphadenopathy and a maculopapular rash on the face and thorax. This case suggests that the clinical syndromes of primary infection with $\mathrm{HIV}-1$ and HIV-2 are similar.

\section{Laboratory findings}

During the first 1 to 1.5 weeks after onset of the acute illness, a marked lymphopenia may develop, which can easily be missed owing to its transient 


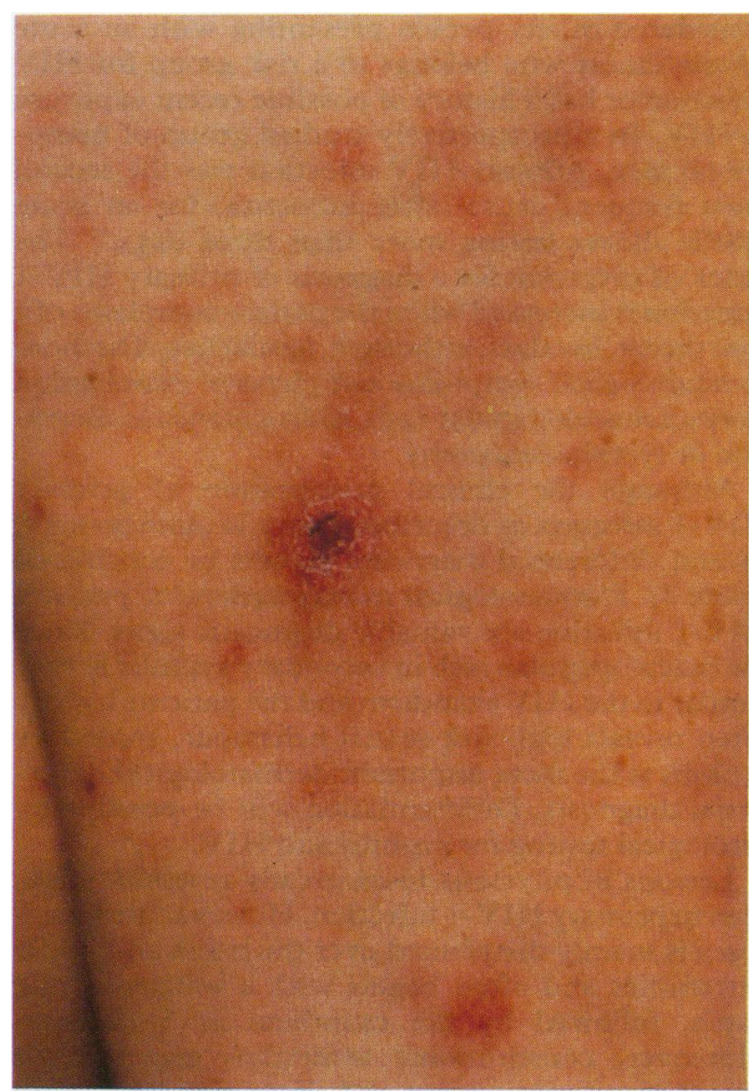

Fig 2 HIV exanthem left fore-arm with roseola-like desquamation.

nature. ${ }^{511} 1830313345$ After the initial lymphopenia the number of lymphocytes increases and lymphocytosis develops. ${ }^{391433353745}$ Concomitant with lymphocytosis, atypical lymphocytes may appear in the peripheral blood. T-cell subset counts during primary HIV-1 infection will be discussed later. In one study, an increase in the proportion of banded neutrophils was found during the first week of the illness and a decrease in segmented neutrophils

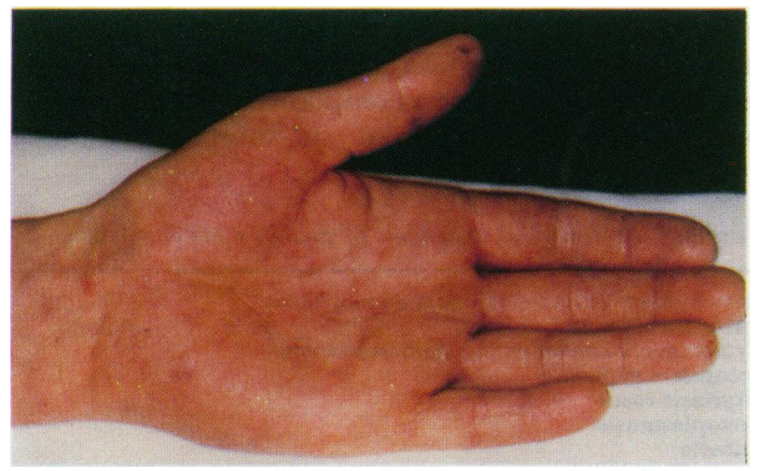

Fig 3 Palmar exanthem in a patient with HIV-1 infection. during the third and fourth weeks. ${ }^{9}$ Within two weeks after onset of symptoms, a thrombocytopenia may develop which is usually mild and asymptomatic. ${ }^{391315303335}$ An increase of the erythrocyte sedimentation rate has also been reported. ${ }^{9}$ Changes in hemoglobin levels have never been described in association with primary HIV-1 infection.

Serum levels of alkaline phosphatase and aspartate transaminase may be elevated. ${ }^{91+1828333740}$ However, clinical signs of hepatitis have seldom been reported. $^{18}$

\section{Virological and immunological findings}

During the early stages of symptomatic primary HIV-1 infection, HIV p24 antigen can be demonstrated in plasma, ${ }^{15162640-50}$ and virus may be isolated from plasma, peripheral-blood lymphocytes and cerebrospinal fluid, ${ }^{13} 34+7851$ usually before seroconversion to HIV antibodies occurs. Following seroconversion, HIV p24 antigen generally decreases to undetectable levels and virus can less frequently be isolated..$^{1516253132+8}$ Usually this viral clearance coincides with clinical improvement. ${ }^{15} 313251$ Persistent HIV antigenaemia seems to predispose to an early progression to AIDS..$^{18253}$ In some cases a windowphase may occur in which HIV antigenaemia has disappeared prior to the appearance of HIV antibodies and thus no serological markers for HIV-1 infection can be detected. ${ }^{33}$

In two recent studies, the viral load during the acute illness has been quantified and related to antibody response and clinical course. ${ }^{31}{ }^{32}$ Plasma virus- and HIV p24 antigen titres during the clinical illness were high and comparable with those reported for patients with AIDS or AIDS-related complex. Decreases in viral load coincided with clinical improvement and the appearance of HIV antibodies. Levels of plasma virus- and HIV p24 antigen were undetectable 9-75 days after onset of symptoms. Transient HIV antigenaemia and virus isolation prior to seroconversion have also been demonstrated in individuals without an apparent clinical illness. ${ }^{+46+85054}$ However, quantification of viral load has never been done in such people. It is possible that asymptomatic seroconverters have lower levels of viraemia. At any rate, the findings in all studies imply that a period exists during primary HIV-1 infection in which no HIV antibodies can be demonstrated while viraemia is present and the patient may be highly infectious.

The biological phenotype of the visus isolated during primary HIV-1 infection may have prognostic significance, that is, those people in whom a syncytium-inducing (SI) HIV variant is found appear to progress far more rapidly to AIDS than those in whom non-syncytium-inducing (NSI) 
Table 2 Serological profiles during and diagnostic of primary HIV infection

\begin{tabular}{llll}
\hline At the onset of illness & \multicolumn{2}{l}{ Several weeks later } \\
\hline p24 antigen & anti-HIV-Ab & p24 antigen & anti-HIV-Ab \\
+ & - & - & + \\
- & - & - & + \\
+ & - & + & + \\
- & - & + & + \\
\hline
\end{tabular}

viruses are isolated (Tersmette $M$, et al submitted for publication).

During symptomatic primary HIV-1 infection, HIV antibodies are usually demonstrable within the first weeks after onset of clinical symptoms. Preceding the IgG response, IgM antibodies may be detectable within 1-2 weeks after onset of the illness. ${ }^{65-57}$ After $2-5$ weeks peak levels are reached and then decrease to undetectable levels within 3 months. However, since an absent early IgM response has been reported in a proportion of patients, a negative result is not conclusive. ${ }^{6} \mathrm{HIV}$ specific IgG antibodies are usually detected 2-6 weeks after onset of the illness. ${ }^{646-48} 5758$

Serological profiles that may be encountered in, and are diagnostic of primary HIV-1 infection are represented in table 2 . In case a patient presents when already HIV-Ab seropositive (with or without concurrent HIV p24 antigenaemia), the longitudinal profile of antibodies directed against different HIV antigens may be helpful in establishing whether this is a fairly recent infection..$^{59}$

The peripheral lymphocyte count is decreased during the early stages of the acute illness, affecting both $\mathrm{CD} 4+$ as well as CD8 + lymphocytes. ${ }^{5460}$ $\mathrm{CD} 4+$ cell counts can be as low as those seen in patients with AIDS, which may explain the occurrence of oral- and oesophageal candidiasis during primary HIV-1 infection. ${ }^{61}$ However, the lymphopenia is transient and is followed by lymphocytosis. Although $\mathrm{CD} 4+$ cell counts rise as well, T-cell subset counts show that the development of lymphocytosis is mainly due to an increase of circulating $\mathrm{CD} 8+$ lymphocytes with progressive inversion of the $\mathrm{CD} 4+/ \mathrm{CD} 8+$ ratio. ${ }^{3456062}$ After approximately 4-5 weeks the level of CD8 + cells reaches a peak and returns to normal values in the following months. Since CD8 + levels remain higher than CD4+ levels, the inverted CD4 +/CD8 + ratio persists. ${ }^{5450}$

Early signs of a host response to primary HIV-1 infection include a transient appearance of interferon-alpha in the blood and raised levels of neopterin and beta $_{2}$-microglobulin. ${ }^{60}$ Initially increased beta ${ }_{2}$-microglobulin levels correlate with the rate of decline of $\mathrm{CD} 4+$ cell counts in the ensuing years.

Differential diagnosis

A diagnosis of primary HIV-1 infection should be considered in any person presenting with an acute febrile illness who belongs to a risk group for HIV infection or has a history of possible recent exposure to HIV. In a prospectively studied group of homosexual men, primary HIV infection was the second most frequent cause (after influenza) for an acute febrile illness lasting more than three days. ${ }^{64}$ The index of suspicion for a diagnosis of primary HIV-1 infection is increased when the patient complains of a sore throat, myalgia, arthralgia, headaches, diarrhoea or neurological symptoms and physical examination shows a maculopapular rash, mucocutaneous ulceration or lymphadenopathy.

Although the clinical presentation of primary HIV-1 infection as described above is quite distinct, several differential diagnoses should be considered (table 3). Dermatological manifestations of primary HIV-1 infection are valuable diagnostic signs. Since the maculopapular rash in secondary syphilis is very similar to the HIV exanthem and the patients history often reveals high risk sexual behaviour, secondary syphilis is the most important dermatological differential diagnosis. Differentiation will be possible by serological testing for syphilis and HIV.

Lesions in pityriasis rosea greatly resemble those seen in primary HIV-1 infection. However, pityriasis rosea is mainly distributed over the trunk and upper extremities and often begins with a solitary herald patch, followed by the exanthem in 5-15 days. Moreover, constitutional symptoms are mild or absent in pityriasis rosea and there may be mild to moderate pruritus.

CMV and toxoplasma infections are usually not associated with an exanthem. In rubella the palms and soles are not affected. In patients using medication, especially antibiotics, a drug eruption should be included in differential diagnosis.

The previously described mucocutaneous ulceration in primary HIV-1 infection is an unusual finding in most other diagnoses and may aid in differentiation.

As is suggested by the CDC definition, the clinical features of EBV infectious mononucleosis and primary HIV-1 infection are similar. However, there are some distinct differences which may enable differentiation. ${ }^{65}$ In infectious mononucleosis, the onset of the illness is insiduous rather than acute. Although a sore throat is a common complaint in both illnesses, examination of the throat in infectious mono-

\section{Table 3 Differential diagnoses of primary HIV infection}

Epstein-Barr virus infectious mononucleosis Influenza

Cytomegalovirus infectious mononucleosis

Secondary syphilis

Pityriasis rosea

Toxoplasmosis

Rubella

Drug allergy 
nucleosis usually reveals tonsillar enlargment and exsudative plaques, whereas in primary $\mathrm{HIV}-1$ infection findings usually are pharyngeal oedema and hyperaemia. Moreover, in primary HIV-1 infection ulcers may be seen on the buccal mucosa, gingiva, palate or tonsils, whereas oral ulceration is a rare finding in infectious mononucleosis and, if present, is restricted to the tonsils. In contrast with primary HIV-1 infection, infectious mononucleosis is infrequently associated with a rash. Other symptomatological differences are a relatively high incidence of splenomegaly, jaundice and elevated serum levels of liver enzymes in infectious mononucleosis when compared to primary HIV-1 infection, and a relatively high incidence of diarrhoea in primary HIV-1 infection when compared with infectious mononucleosis. Lymphocytosis with increased numbers of CD8 + lymphocytes is found in both illnesses. Although the appearance of atypical lymphocytes in the peripheral blood is also a feature of both diseases, the incidence of atypical lymphocytosis appears to be considerably lower in primary HIV-1 infection than in infectious mononucleosis.

A definite diagnosis can usually be made by serological testing for both HIV and EBV. However, a false positive Paul-Bunnel test during primary HIV1 infection has been reported. ${ }^{38} \mathrm{~A}$ pitfall in diagnosis may thus occur, considering the previously mentioned window phase during primary HIV-1 infection, in which no serological markers for HIV can be detected.

\section{Therapeutic options}

Treatment with the antiretroviral drug zidovudine (3'-azido-3'-deoxythymidine, AZT, Retrovir ${ }^{\mathfrak{k}}$ ) has led to substantial clinical benefits, transient immunological improvement and suppression of viral replication in patients with late stage HIV-disease and in asymptomatic HIV infected subjects with peripheral blood CD4 + lymphocyte counts below $500 / \mathrm{mm}^{3}$.66 67

A few people with recently acquired HIV infection have received zidovudine. In an Australian-Swedish study, 11 subjects with symptomatic primary HIV-1 infection were treated with $1 \mathrm{~g}$ zidovudine daily for a median period of 56 days. Compared with a group of historical controls, there was no clear evidence of any clinical benefit in terms of resolution of the acute illness and no indication that the treatment would prevent development of persistent infection. ${ }^{68}$ In three cases of accidental or suicidal inoculation with HIV infected blood, zidovudine-treatment instituted within 45 minutes to 6 hours after inoculation, failed to prevent the establishment of HIV infection. ${ }^{69-71}$

Thus, although experience with antiretroviral treatment of primary HIV infection is very limited, on the basis of the data available at present, it appears unjustified to prescribe zidovudine to persons with primary HIV infection outside the setting of a controlled trial.

\section{Conclusion}

Symptomatic primary HIV-1 infection is a more distinct clinical syndrome than appears from the CDC definition. Moreover, the clinical spectrum of primary HIV-1 infection is more extensive than has been outlined in the CDC definition. Considering the occurrence of oral and oesophageal candidiasis in association with low levels of circulating CD4+ lymphocytes and high levels of serum HIV p24 antigen, the clinical syndrome may even resemble AIDS-related complex or AIDS.

If primary infection with HIV-1 is suspected in a patient, a definite diagnosis can be made by finding a diagnostic serological profile (table 2). Considering the occurrence of a window-phase in which no serological markers for HIV-1 infection can be detected, a failure to demonstrate HIV p24 antigen does not exclude primary HIV-1 infection. Sequential testing for HIV antibodies in the serum to document seroconversion, is necessary to prevent this pitfall in diagnosis of primary HIV-1 infection.

Clinical recognition of primary infection with HIV is of importance in controlling the spread of the AIDS epidemic, since counselling efforts to limit spread of the infection can be made at an early stage of HIV infection. Early monitoring of infected persons may be of importance in optimal targetting of antiretroviral therapeutic intervention. Controlled studies are needed to assess the value of zidovudine in the treatment of primary HIV infection.

Address for correspondence: JMA Lange, National AIDS Therapy Evaluation Centre, room F5-160, Academic Medical Centre, University of Amsterdam, Meibergdreef 9, $1105 \mathrm{AZ}$ Amsterdam, The Netherlands.

1 Centers for Disease Control. Classification system for human T-lymphotropic virus type III/lymphadenopathy-associated virus infection. $M M W R$ 1986;35:334-9.

2 Tindall B, Cooper DA. Primary HIV infection: host responses and intervention strategies. $A I D S$ 1991;5:1-14.

3 Cooper DA, Gold JA, Maclean P, et al. Acute retrovirus infection. Definition of a clinical illness associated with seroconversion. Lancet $1985 ; \mathbf{i}: 537-40$.

4 Pedersen C, Lindhardt BO, Jensen BL, et al. Clinical course of primary HIV infection: consequences for subsequent course of infection. $B M J 1989 ; 299: 154-7$.

5 Tindall B, Barker S, Donovan B, et al. Characterisation of the acute clinical illness associated with human immunodeficiency virus infection. Arch Intern Med 1988;148:945-9.

6 Lange JMA, Parry JV, De Wolf F, Mortimer PP, Goudsmit J. Diagnostic value of specific IgM antibodies in primary HIV infection. $A I D S$ 1988;2:31-5.

7 Reiss P, Lange JMA, Goudsmit J. LAV/HTLV III infectie na eenmalig sexueel contact met een AIDS-patiënt. Ned Tijdschr Geneesk 1985;129:1933-4.

8 Anonymous. Needlestick transmission of HTLV-III from a patient infected in Africa (editorial). Lancet 1984;ii:1376-7. 
9 Gaines H, Von Sydow M, Pehrson PO, Lundbergh P. Clinical picture of primary HIV infection presenting as a glandularfever-like illness. $B M J$ 1988;297:1363-8.

10 Stricof RL, Morse DL. HTLV III/LAV seroconversion following a deep intramuscular needlestick injury. $N$ Engl $J$ Med 1986;314:1115.

11 Tucker J, Ludlam CA, Craig A, et al. HTLV-III infection associated with glandular-fever-like illness in a haemophiliac (letter). Lancet 1985;i:585.

12 Oksenhendler E, Harzic M, Le Roux JM, Rabian C, Clauvel JP. HIV infection with seroconversion after a superficial needlestick injury to the finger (letter). $N$ Engl J Med 1986;315:582.

13 Ho DD, Sarngadharan MG, Resnick L, et al. Primary human Tlymphotropic virus type III infection. Ann Intern Med 1985; 103:880-3.

14 Carne CA, Smith A, Elkington SG, et al. Acute encephalopathy coincident with seroconversion for anti-HTLV-III. Lancet 1985;ii:1206-8.

15 Kessler HA, Blaauw B, Spear J, et al. Diagnosis of human immunodeficiency virus infection in seronegative homosexuals presenting with acute viral syndrome. JAMA 1987;258: 1196-9.

16 Von Sydow M, Gaines H, Sönnerborg A, et al. Antigen detection in primary HIV infection. BMJ 1988;296:238-40.

17 Rabeneck L, Popovic M, Gartner S, et al. Acute HIV infection presenting with painful swallowing and esophageal ulcers. $J A M A$ 1990;263:2318-22.

18 Oksenhendler E, Harzic M, Le Roux JM, Rabian C, Clauvel JP. HIV infection with seroconversion after a superficial needlestick injury to the finger (letter). $N$ Engl J Med 1986;315:582.

19 Griffith BP, Ferguson D, Mellors JW. Acute human immunodeficiency virus infection: false-negative ELISA in a patient with viremia and a positive western blot test. $J$ Infect Dis 1989;160:160-1.

20 McMillan A, Bishop PE, Aw D, Peutherer JF. Immunohistology of the skin rash associated with acute HIV infection. AIDS 1989;3:309-12.

21 Van Gelder T, Kroes ACM, Van der Ende ME. Acute HIVinfection: report of a case and a review of recent developments. Neth J Med 1990;37:154-7.

22 Del Rio C, Soffer O, Widell JL, Judd RL, Slade BA. Acute human immunodeficiency virus infection temporally associated with rhabdomyelysis, acute renal failure, and nephrosis. Rev Infect Dis 1990;12:282-5.

23 Mahé A, Bruet A, Chabin E, Fendler JP. Acute rhabdomyolysis coincident with primary HIV-1 infection (letter). Lancer 1989;ii:1454-5.

24 Anonymous. Case records of the Massachussets General Hospital. Case 33-1989. N Engl J Med 1989;321:454-63.

25 Isaksson B, Albert J, Chiodi F, et al. AIDS two months after primary human immunodeficiency virus infection. $J$ Infect $D i$ 1988;158:866-8.

26 Wall RA, Denning DW, Amos A. HIV antigenaemia in acute HIV infection (letter). Lancet 1987; : 566.

27 Elder G, Dalakas M, Pezeshkpour G, Sever J. Ataxic neuropathy due to ganglioneuritis after probable acute human immunodeficiency virus infection (letter). Lancet 1986;ii:1275-6.

28 Biggar JR, Johnson BK, Musoke SS, et al. Severe illness associated with appearance of antibody to human immunodeficiency virus in an African. $B M J$ 1986;293:1210-1.

29 Lange Wantzin GR, Lindhardt BO, Weismann $\mathrm{K}$, Ulrich $\mathrm{K}$. Acute HTLV-III infection associated with exanthema, diagnosed by seroconversion. Br J Dermatol 1986;115:601-6.

30 Lindskov R, Lindhardt BO, Weismann K, et al. Acute HTLVIII infection with roseola-like rash (letter). Lancet 1986; i:447.

31 Clark SJ, Saag MS, Decker WD, et al. High Titers of cytopathic virus in plasma of patients with symptomatic primary HIV-1 infection. N Engl J Med 1991;324:954-60.

32 Daar ES, Moudgil T, Meyer RD, Ho DH. Transient high levels of viremia in patients with primary human immunodeficiency virus type 1 infection. $N$ Engl J Med 1991;324:961-4.

33 Claessen FAP, Goudsmit J, Lange JMA. Primaire infecties met het humane immunodeficiëntievirus. Ned Tijdschr Genees 1990;134:1073-7.

34 Calabrese LH, Profitt MR, Levin KH, Yenlieberman B, Starkey C. Acute infection with the human immunodeficiency virus (HIV) associated with acute brachial neuritis and exanthematous rash. Ann Intern Med 1987;107:849-51.

35 Reiss P, Razenberg PPA, De Geus JP, Schellekens PTA. Een patiënt met een licht verlopende vorm van verworven immunodeficiëntie syndroom (AIDS)? Ned Tijdschr. Geneesk. 1983;127:824-5.

36 Pedersen C, Nielsen JO, Dickmeis E, Jordal R. Early progres- sion to AIDS following primary HIV infection (letter). AIDS 1989;3:45-46.

37 Piette AM, Tusseau F, Vignon D, et al. Acute neuropathy coincident with seroconversion for anti-LAV/HTLV-III (letter). Lancet $1986 ; \mathbf{i}: 852$.

38 Van Essen GG, Lieverse AG, Sprenger HG, Schirm J, Weits J False positive Paul-Bunnell test in HIV seroconversion (letter). Lancet 1988;i:747-8.

39 Wallace MR, Harrison WO. HIV seroconversion with progressive disease in health care worker after needlestick injury. Lancet 1988;ii: 1454 .

40 Denning DW, Anderson J, Rudge P, Smith H. Acute myelopathy associated with primary infection with human immunodeficiency virus, $B M J$ 1987;294:143-4.

41 Wiselka MJ, Nicholson KG, Ward SC, Flower AJE. Acute infection with human immunodeficiency virus associated with facial nerve palsy and neuralgia. $J$ Infect Dis 1987;15:189-94.

42 Hagberg L, Malmvall BE, Svennerholm L, Alestig K, Norkrans G. Guillain-Barré syndrome as an early manifestation of HIV central nervous system infection. Scand J Infect Dis 1986; 18:591-2.

43 Hulsebosch HJ, Claessen FAP, Van Ginkel CJW, et al. Human immunodeficiency virus exanthema. J Am Acad Dermatol 1990;23:483-486.

44 Besnier JM, Barin F, Baillou A, et al. Symptomatic HIV-2 primary infection (letter). Lancet 1990;i:798.

45 Cooper DA. Tindall B, Wilson EJ, Imrie AA, Penny R. Characterization of $\mathrm{T}$ lymphocyte responses during primary infection with human immunodeficiency virus. $J$ Infect $D i$ 1988;157:889-96.

46 Allain JP, Paul DA, Laurian Y, Senn D. Serological markers in early stages of human immunodeficiency virus infection in haemophiliacs. Lancet 1986;ii:1233-6.

47 Gaines H, Albert J, Von Sydow M, et al. HIV antigenaemia and virus isolation from plasma during primary HIV infection. Lancet 1987;ii: 177-80.

48 Goudsmit J, Paul DA, Lange JMA, et al. Expression of human immunodeficiency virus antigen (HIV-ag) in serum and cerebrospinal fluid during acute and chronic infection. Lancet 1986;i:177-80.

49 Paul DA, Falk LA, Kessler HA, et al. Correlation of serum HIV antigen and antibody with clinical status in HIV-infected patients. J Med Virol 1987;22:357-63.

50 Stramer SL, Heller JS, Coombs RW, et al. Markers of HIV infection prior to IgG antibody seropositivity. JAMA 1989;262:64-69.

51 Albert J, Gaines H, Sönnerborg A, et al. Isolation of human immunodeficiency virus (HIV) from plasma during primary HIV infection. J Med Virol 1987;23:67-73.

52 De Wolf F, Goudsmit J, Paul DA, et al. Risk of AIDS related complex and AIDS in homosexual men with persistent HIV antigenaemia. BMJ 1987;295:569-72.

53 Lange JMA, Paul DA, Huisman HG, et al. Persistent HIVantigenaemia and decline of HIV core antibodies associated with transition to AIDS. BMJ 1986;293:1459-62.

54 Ranki A, Krohn M, Allain JP, et al. Long latency precedes overt seroconversion in sexually transmitted human-immunodeficiency-virus infection. Lancet 1987; i:589-93.

55 Gaines H, Von Sydow M, Parry JV. Detection of immunoglobulin $M$ antibody in primary human immunodeficiency virus infection. AIDS 1988;2:11-15.

56 Healey DS, Maskill WJ, Gust ID. Detection of anti-HIV immunoglobulin $M$ by particle agglutination following acute HIV infection. AIDS 1989;3:301-4.

57 Cooper DA, Imrie AA, Penny R. Antibody response to human immunodeficiency virus after primary infection. $J$ Infect $D$ is 1987; 155:1113-8

58 Gaines H, Von Sydow M, Sönnerborg A, et al. Antibody response in primary human immunodeficiency virus infection. Lancet 1987; i: $1249-53$.

59 Lange JMA, Coutinho RA, Krone WJA, et al. Distinct IgG recognition patterns during progression of subclinical and clinical infection with lymphadenopathy associated virus human T lymphotropic virus. $B M J$ 1986;292:228-30.

60 Gaines H, Von Sydow MAE, Von Stedingk LV, et al. Immunological changes in primary $\mathrm{HIV}-1$ infection. AIDS 1990;4:995-9.

61 Lane HC, Masur H, Gelman EP, et al. Correlation between immunologic function and clinical subpopulations of patients with the acquired immune deficiency syndrome. Am J Med 1985;78:417-22.

62 Pedersen C, Dickmeiss E, Gaub J, et al. T-cell subset alterations and lymphocyte responsiveness to mitogens and antigen 
during severe primary infection with HIV: a case series of seven consecutive HIV seroconverters. AIDS 1990;4:523-6.

63 Hofmann B, Wang Y, Cumberland WG, et al. Serum beta 2 microglobulin level increases in HIV infection: relation to seroconversion, CD4 T-cell fall and prognosis. AIDS 1990; 4:207-14.

64 De Wolf F, Lange JMA, Bakker $M$, et al. Influenza-like syndrome in homosexual men: a prospective diagnostic study. $J$ Royal College Gen Pract 1988;38:443-6.

65 Schooley RT, Down R. Epstein-Barr virus (infectious mononucleosis). In: Mandell GL, Douglas RG, Bennet JE, ed. Principles and Practice of Infectious Diseases. Churchill Livingstone Inc., 1990:1172-85.

66 Fischl MA, Richman DD, Grieco MH, et al. The efficacy of azidothymidine (AZT) in the treatment of patients with AIDS and AIDS-related complex: a double-blind, placebo-controlled trial. N Engl J Med 1987;317:185-91.
67 Volberding PA, Lagakos SW, Hansen N, et al. Zidovudine in asymptomatic human immunodeficiency virus infection: a controlled trial in persons with fewer than $500 \mathrm{CD} 4$-positive cells per cubic millimeter. $N$ Engl J Med 1990;322:941-9.

68 Tindall B, Gaines $\mathrm{H}$, Imrie A, et al. Zidovudine in the management of primary HIV-1 infection. AIDS 1991;5: 477-85.

69 Lange JMA, Boucher CAB, Hollak CEM, et al. Failure of zidovudine prophylaxis after accidental exposure to HIV -1. $N$ Engl J Med 1990;322:1375-7.

70 Looke DFM, Grove DI. Failed prophylactic zidovudine after needlestick injury (letter). Lancet 1990;ii: 1280.

71 Durand E, Le Jeunne C, Hugues FC. Failure of prophylactic zidovudine after suicidal self-inoculation of HIV-infected blood. N Engl J Med 1991;324:1062.

Accepted for publication 7 August 1991 